\title{
From Baker v. Carr to Bush v. Gore, and Back
}

Nelson Lund

Follow this and additional works at: https://scholarlycommons.law.case.edu/caselrev

Part of the Law Commons

\section{Recommended Citation}

Nelson Lund, From Baker v. Carr to Bush v. Gore, and Back, 62 Case W. Rsrv. L. Rev. 947 (2012)

Available at: https://scholarlycommons.law.case.edu/caselrev/vol62/iss4/4

This Symposium is brought to you for free and open access by the Student Journals at Case Western Reserve University School of Law Scholarly Commons. It has been accepted for inclusion in Case Western Reserve Law Review by an authorized administrator of Case Western Reserve University School of Law Scholarly Commons. 


\title{
From BAKER V. CARR TO BUSH V. GORE, AND BACK
}

\author{
Nelson Lund
}

This Article advances three propositions. First, Baker v. Carr $^{1}$ and its early one person, one vote progeny were wrongly decided. Second, in light of the case law generated by these decisions, Bush v. Gore ${ }^{2}$ was correctly decided. Third, even without Baker v. Carr and its progeny, the decision in Bush v. Gore would still have been legally correct.

Justice Harlan proved the first proposition in his dissenting opinions in the early cases, and the majority never even made an effort to respond to his arguments and evidence. I have established the second proposition in a series of articles that have received a similar form of silent treatment from the legal academy. I believe that the third proposition is novel, and that everyone should agree with it, even if they disagree about the first two.

\section{BAKER V. CARR WAS WRONGLY DECIDED}

Justice Frankfurter's impassioned dissent in Baker v. Carr, like Justice Breyer's in Bush v. Gore, contended that the Supreme Court was risking its institutional legitimacy by intruding into political disputes where even the appearance of judicial impartiality would be difficult or impossible to maintain. ${ }^{3}$ Frankfurter soon fell ill and

$\dagger$ Patrick Henry Professor of Constitutional Law and the Second Amendment, George Mason University School of Law. For helpful comments, I am grateful to Stephen G. Gilles, John O. McGinnis, and David N. Schleicher. George Mason's Law and Economics Center generously provided research support.

1369 U.S. 186 (1962).

2531 U.S. 98 (2000).

3 Baker, 369 U.S. at 267 (Frankfurter, J., dissenting):

Disregard of inherent limits in the effective exercise of the Court's 'judicial Power'... may well impair the Court's position as the ultimate organ of 'the 
retired, so he was not there to watch as the Court's apportionment revolution took place quickly and without significant political resistance. Baker v. Carr is now among the least controversial landmarks of the Warren Court. Breyer's portentous concern with the public's confidence in the Court also appears to have been misplaced. ${ }^{4}$ Notwithstanding the clamorous and continuing howls of outrage from the legal academy about Bush v. Gore, ${ }^{5}$ the public's confidence in the Court appears to have been unaffected. ${ }^{6}$

When we look back at Baker v. Carr, there is a natural temptation to focus on Justice Brennan's famous six-factor restatement of the political question doctrine, and on the role of this case in fulfilling the visionary dicta of Carolene Products' footnote 4. It is easy to see the kind of unequal apportionment that was challenged in Baker v. Carr and its early progeny as an obvious failure of ordinary political processes, and one that only federal courts could correct because

supreme Law of the Land' in that vast range of legal problems, often strongly entangled in popular feeling, on which this Court must pronounce. The Court's authority-possessed of neither the purse nor the sword-ultimately rests on sustained public confidence in its moral sanction. Such feeling must be nourished by the Court's complete detachment, in fact and in appearance, from political entanglements and by abstention from injecting itself into the clash of political forces in political settlements.

4 Bush, 531 U.S. at 157-58 (Breyer, J., dissenting) (quoting D. LoTH, ChIEF JustiCE John MARshall AND THE GROWTH OF THE AMERICAN REPUBLIC 365 (1948)):

[A]bove all, in this highly politicized matter, the appearance of a split decision runs the risk of undermining the public's confidence in the Court itself. That confidence is a public treasure. It has been built slowly over many years, some of which were marked by a Civil War and the tragedy of segregation. It is a vitally necessary ingredient of any successful effort to protect basic liberty and, indeed, the rule of law itself. We run no risk of returning to the days when a President (responding to this Court's efforts to protect the Cherokee Indians) might have said, 'John Marshall has made his decision; now let him enforce it!' But we do risk a self-inflicted wound-a wound that may harm not just the Court, but the Nation.

5 See, e.g., Nelson Lund, A Very Streamlined Introduction to Bush v. Gore, 23 ST. THOS. L. REV. 449 (2011) (refuting several criticisms of Bush v. Gore); Nelson Lund, Bush v. Gore at the Dawning of the Age of Obama, 61 FLA. L. REV. 1001 (2009) [hereinafter Lund, Dawning] (responding to Professor Akhil Amar's critique of Bush v. Gore); Nelson Lund, Bush v. Gore: The Question of Legitimacy, 4 Engage: THE JOURNAL OF THE FEDERALIST SOCIETY'S PRACTICE GROUPS, No. 1 May 2003, at 154, available at www.fedsoc.org/publications/detail/nelson-lund-reviews-bush-v-gore-the-question-of-legitimacy-editedby-bruce-ackerman [hereinafter Lund, Question of Legitimacy] (reviewing a collection of essays, almost all of which were severely critical of Bush v. Gore); Nelson Lund, The Unbearable Rightness of Bush v. Gore, 23 CARDOZO L. REV. 1219 (2002) [hereinafter Lund, Unbearable Rightness] (responding to early criticisms of Bush v. Gore).

6 See, e.g., Nathaniel Persily, Foreword: The Legacy of Bush v. Gore in Public Opinion and American Law, 23 ST. Thomas L. REV. 325, 325-26 n. 2 (2011) (citing scholarship and public opinion polls suggesting that the "initial polarization toward the Court evaporated within a year of the decision"). 
incumbent politicians had all the wrong incentives. Frankfurter doubted that the political process could be reformed using a judicially manageable legal doctrine, ${ }^{7}$ but he was soon proved wrong. The very next year, the Court promulgated a simple legal rule-one person, one vote - that it has been able to apply without much difficulty. ${ }^{8} \mathrm{~A}$ few decisions have produced odd results, ${ }^{9}$ and a few exceptions were eventually created, ${ }^{10}$ but it would not be easy to find many legal rules about which the same could not be said. As judicial statesmanship goes, and perhaps as legal craftsmanship goes as well, not a bad performance. Game over.

Or so it would seem. Frankfurter and Breyer both cited Alexander Bickel's ode to "the passive virtues."11 Appeals to this form of judicial restraint are frequently offered as a substitute for legal analysis, and they ring a little hollow when the active virtues (or vices) produce results that become well accepted. But if we take a closer look at Baker v. Carr and its early progeny, a somewhat different critique emerges from the dissenting opinions of Justice Harlan. Although he joined Frankfurter's opinion in Baker v. Carr, he also wrote a dissent of his own, which Frankfurter joined. ${ }^{12}$ Harlan's opinion did not focus on the political question doctrine or the political

7 See Baker, 369 U.S. at 268 (Frankfurter, J., dissenting) ("Even assuming the indispensable intellectual disinterestedness on the part of judges in such matters, they do not have accepted legal standards or criteria or even reliable analogies to draw upon for making judicial judgments.").

8 Gray v. Sanders, 372 U.S. 368, 381 (1963). In at least one respect, Frankfurter may have been right. As Justice Harlan later pointed out in his dissenting opinion in Reynolds $v$. Sims, one effect of the Court's apportionment decisions would be to create pressure for partisan gerrymandering, which can itself be understood as a form of vote dilution or vote discrimination. 377 U.S. 533, 622 (1964) (Harlan, J., dissenting). What would happen when the Court's distaste for unequal districts and for gerrymandering collided? As we now know, it has left the Court in utter disarray, with the decisive vote being cast by a Justice who has decided to wait for someone to think up a solution to the problem. See Vieth v. Jubelirer, 541 U.S. 267, 281 (2004) (plurality opinion) (political gerrymandering claims are nonjusticiable because no judicially discernible and manageable standards for adjudicating such claims exist); $i d$. at 311 (Kennedy, J., concurring in the judgment) ("That no such [workable] standard has emerged in this case should not be taken to prove that none will emerge in the future.").

9 See, e.g., City of Phoenix v. Kolodziejski, 399 U.S. 204 (1970) (referenda on municipal general obligation bonds may not be restricted to property taxpayers); Cipriano v. City of Houma, 395 U.S. 701 (1969) (referenda on municipal revenue bonds may not be restricted to property taxpayers); Kramer v. Union Free Sch. Dist. No. 15, 395 U.S. 621 (1969) (local school boards may not be elected solely by those who pay taxes to support the schools or have children attending the schools).

10 See, e.g., Rodriguez v. Popular Democratic Party, 457 U.S. 1 (1982) (vacancies in a legislature may sometimes be temporarily filled by an election that does not comply with the one person, one vote principle); Ball v. James, 451 U.S. 355 (1981) (certain special assessment districts may limit the franchise to those disproportionately affected by the district's activities); Salyer Land Co. v. Tulare Lake Basin Water Storage Dist., 410 U.S. 719 (1973) (same).

11 See Bush v. Gore, 531 U.S. 98, 157-58 (2000) (Breyer, J., dissenting); Baker, 369 U.S. at $281 \mathrm{n} .10$ (Frankfurter, J., dissenting).

12 Baker, 369 U.S. at 330 (Harlan, J., dissenting). 
risks that the Court was running. Instead, he asked a very pointed and uncomfortable legal question: how could the unequal apportionment of the Tennessee legislature - the practice challenged in Baker $v$. Carr - possibly be thought to violate the Constitution? ${ }^{13}$

There were two major holdings in Baker v. Carr. ${ }^{14}$ First, nonjusticiable "political questions," including those found in Guarantee Clause cases, arise from the relationship between the judiciary and the coordinate branches of the federal government, not between federal courts and the states. The resulting doctrine is therefore a function primarily of the separation of powers, not federalism, and does not apply to challenges brought against state apportionment schemes. ${ }^{15}$ Second, the federal courts have subjectmatter jurisdiction to resolve claims that a state's irrational apportionment of its legislature violates the Fourteenth Amendment. ${ }^{16}$ For present purposes, I am happy to accept the validity of both the justiciability and jurisdictional holdings. ${ }^{17}$ As Harlan pointed out, however, the majority failed to explain why the district court's dismissal of the case should not be affirmed on a separate ground: the complaint failed to state a claim upon which relief can be granted. ${ }^{18}$

Harlan's argument for dismissing the case had four main points. First, there is no general constitutional principle requiring equipopulous districts, as the U.S. Senate proves. ${ }^{19}$ Second, a requirement of equipopulous legislative districts had no basis in our

13 Id. at 330-31.

14 The Court also held that the plaintiffs had standing. Id. at 206 (majority opinion).

$15 \mathrm{Id}$. at 210 ("[I]n the Guaranty Clause cases and in the other 'political question' cases, it is the relationship between the judiciary and the coordinate branches of the Federal Government, and not the federal judiciary's relationship to the States, which gives rise to the 'political question."').

16 Id. at 204.

17 Whether or not Brennan's restatement of the political question doctrine accurately distilled the case law, and whether or not his restatement is a correct interpretation of the Constitution in all respects, the Court decided long ago that Fourteenth Amendment challenges to state districting decisions are justiciable. McPherson v. Blacker, 146 U.S. 1, 16-17 (1892) (resolving Fourteenth Amendment challenge to a state's use of districts rather than at-large elections in choosing presidential electors). As for the jurisdictional holding, even Frankfurter and Harlan acknowledged that the district court "had jurisdiction in the very restricted sense of power to determine whether it could adjudicate the claim." Baker, 369 U.S. at 330 (Frankfurter, J., dissenting).

18 Baker, 369 U.S. at 330-31 (Harlan, J., dissenting) (citing FED. R. CIV. P. 12(b)(6)).

19 Id. at 333. The Senate, the Electoral College, and the requirement that every state have at least one Representative also prove, quite apart from the majority's discussion of the Guarantee Clause and the political question doctrine, that equipopulous districts cannot possibly be required for a state to have a republican form of government. Brennan correctly argued that these constitutional provisions do not themselves establish that other constitutional provisions for other elections might not require equipopulous districts. But the Constitution's own deviations from the principle of equal districts do show that a requirement of equal districts is not an underlying principle of the Constitution. 
legal tradition or in the legislative history of the Fourteenth Amendment, and many states did not adhere to this rule in 1868 or adopt it in the wake of ratification. ${ }^{20}$ Third, the Court had repeatedly and recently rejected challenges to unequal districts. ${ }^{21}$ Fourth, Tennessee's apportionment plan easily survived scrutiny under the applicable rational basis test for violations of the Equal Protection Clause. $^{22}$

Brennan's majority opinion completely ignored all of the evidence about the original meaning of the Fourteenth Amendment. He did seek to distinguish the numerous precedents upholding unequal districts, by characterizing them either as Guarantee Clause cases (rather than Fourteenth Amendment cases) or as instances of judicial restraint by courts of equity. ${ }^{23}$ One wonders why such equitable restraint would suddenly become inoperative if the plaintiffs in this case prevailed on the merits of their claim, but Harlan's crucial argument was that they could not in any event prevail under existing law.

Here is Brennan's entire analysis of that question: "Judicial standards under the Equal Protection Clause are well developed and familiar, and it has been open to courts since the enactment of the Fourteenth Amendment to determine, if on the particular facts they must, that a discrimination reflects no policy, but simply arbitrary and capricious action." ${ }^{24}$ Brennan cited no cases setting forth these "well developed and familiar" judicial standards. But that does not mean he was wrong to say they existed. In fact, there were such standards, and Harlan accurately described them:

All that is prohibited is "invidious discrimination" bearing no rational relation to any permissible policy of the State.... And in deciding whether such discrimination has been practiced by a State, it must be borne in mind that a "statutory discrimination will not be set aside if any state of facts reasonably may be conceived to justify it." ${ }^{25}$

${ }^{20}$ Id. (citing the detailed discussion in Frankfurter's dissent). Two years later, Harlan himself presented an even more comprehensive textual and historical analysis. Reynolds v. Sims, 377 U.S. 533, 593-615, 625-32 (1964) (Harlan, J., dissenting).

21 Baker, 369 U.S. at 334 (Harlan, J., dissenting) (citing McGowan v. Maryland, 366 U.S. 420, 425-26 (1961); Allied Stores of Ohio v. Bowers, 358 U.S. 522, 527-28 (1959)). This point is developed in more detail in Frankfurter's dissent. Id. at 277-80 (Frankfurter, J., dissenting).

22 Id. at 333-37 (Harlan, J., dissenting).

23 Id. at 217-32 (majority opinion).

24 Id. at 226.

25 Id. at 334-35 (Harlan, J., dissenting) (quoting Williamson v. Lee Optical Co., 348 U.S. 483, 489 (1955), and McGowan, 366 U.S. at 426, respectively). Justice Douglas, the author of Lee Optical, acknowledged that this was the governing standard and that "[u]niversal equality is 
Brennan made no effort to refute Harlan's argument that the Tennessee apportionment easily survived under this standard. ${ }^{26}$ Tennessee had not reapportioned its legislature for sixty years, and urban areas had during that time experienced faster population growth than the rural areas. $^{27}$ In Harlan's view, the legislature could rationally have decided to refrain from reapportionment in order to preserve a desirable geographic and demographic balance and to foster governmental stability. ${ }^{28}$ Even if the legislature deliberately sought to protect the state's agricultural interests from being overwhelmed by the sheer numbers of city dwellers, that would no more violate the Equal Protection Clause than tax statutes that favor agricultural interests. ${ }^{29}$ This is a straightforward application of standard rational basis review, and the analogy with tax statutes shows why cases involving racial or religious discrimination were irrelevant.

Together with his stony silence about the original meaning of the Fourteenth Amendment, Brennan's casual disregard of Harlan's other legal arguments suggested that the Court's detailed effort to find only narrow and distinguishable holdings in the precedents was little more than a groundbreaking ceremony. The next three major cases, which came in short order, confirmed that hint. Within two years, the Court announced the one person, one vote rule and applied it, in slightly different versions, to elections to statewide offices, to congressional elections, and to state legislatures. In each case, Harlan argued in detail that the decision had no basis either in the Constitution or in any other kind of law.

In Gray v. Sanders,${ }^{30}$ the Court reviewed Georgia's use of a "county unit" system in primary elections for the U.S. Senate and other statewide offices. Under this system, each county was allocated a number of "unit votes" depending on its population, and a candidate was required to win a majority of these unit votes to secure the nomination. ${ }^{31}$ The practical effect was to give greater weight to

not the test; there is room for weighting." Baker, 369 U.S. at 244-45 (Douglas, J., concurring) (citing Lee Optical, 348 U.S. at 489).

26 Justice Clark's concurring opinion did make an effort to show that the Tennessee apportionment was utterly irrational. Id. at 253-58 (Clark, J., concurring). Harlan responded with a patient explanation of Clark's misunderstanding of statistics and of the relation between statistical disparities and other factors that may legitimately go into legislative apportionment decisions. Id. at 340-49 (Harlan, J., dissenting).

27 Id. at 191 (majority opinion).

${ }_{28} I d$. at 336 (Harlan, J., dissenting).

${ }_{29} \mathrm{Id}$.

30372 U.S. 368 (1963).

31 Id. at 371. 
individual votes in the less populous counties. Thus, for example, the most populous county had about 14 percent of the state's population, but it was allocated less than 2 percent of the county unit votes. ${ }^{32}$

The Court declared that this system violated the Equal Protection Clause. Justice Douglas's majority opinion dismissed the analogy of the Electoral College on the ground that it was "the result of specific historical concerns" 33 and found the basis for the Court's decision elsewhere: "The conception of political equality from the Declaration of Independence, to Lincoln's Gettysburg Address, to the Fifteenth, Seventeenth, and Nineteenth Amendments can mean only one thing -one person, one vote." 34

Harlan pointed out that whatever the motives for the design of the Electoral College, it is certainly in the Constitution and is not based on the one person, one vote "conception of political equality." ${ }^{35} \mathrm{He}$ did not bother to mention that the Declaration of Independence and the Gettysburg Address are not in the Constitution, and that, in any event, neither of these documents articulated the one person, one vote principle. But he did point out that guaranteeing the right to vote to all racial groups and to women, and providing for the election of Senators "by the people," implies nothing at all about the permissibility of weighting votes geographically. ${ }^{36}$ As in Baker $v$. Carr, he explained why favoring rural counties easily passed the applicable rational basis test under the Equal Protection Clause. ${ }^{37}$ And, as in Baker v. Carr, the majority made not the slightest effort to respond to Harlan's arguments. The majority simply made up the one person, one vote principle out of thin air, with no identified basis in the constitutional text, or its history, or in the Court's precedents.

The next year, the Court took a new approach in striking down Georgia's non-equipopulous congressional districts. Justice Black's majority opinion in Wesberry $v$. Sanders ${ }^{38}$ argued that the original meaning of the Constitution requires that these districts must be equipopulous "as nearly as is practicable." ${ }^{39}$ The Constitution, of course, says no such thing. Black read this conclusion into Article I, section 2's requirement that Representatives be chosen "by the People of the several States," relying primarily on statements at the

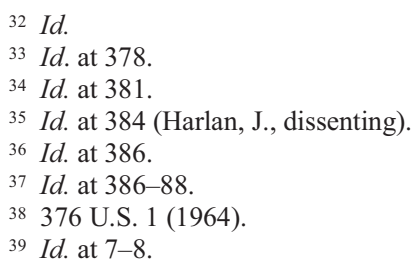


Philadelphia Convention and shortly thereafter during the ratification debates. ${ }^{40}$

A number of the quotations offered by Justice Black appear on their face to support his conclusion. Justice Harlan, however, showed that not a single one of them actually does so. ${ }^{41}$ The fundamental mistake in Black's analysis arises from his conflation of the Constitution's requirement that Representatives be distributed among the states according to their population with the very different question of how representation among localities should be distributed within each state. Every single one of the quotations on which Black relied had to do with the first question. The issue in Wesberry, however, had to do with the second question.

On the relevant question, the text and history of the Constitution are quite clear and quite opposed to Black's position. First, Article I, section 2 permits the states to completely disqualify from the franchise any group that it chooses to disqualify. ${ }^{42}$ Even if the power to deny the vote completely did not imply a lesser power to dilute its effectiveness, Article I, section 4 unambiguously gives the states discretion in regulating the times, places, and manner of holding these elections. ${ }^{43}$ In order to protect against abuse of this power, the Constitution expressly gives Congress authority to override the states' decisions and provide its own regulations. ${ }^{44}$ This provision implies that Congress's power to override state decisions is exclusive, and is not shared with the courts or imposed by the Constitution itself. Harlan showed that this inference is supported by Framing-era discussions, none of which adverted to anything like a one person, one vote rule of equality. ${ }^{45}$ Justice Black made no effort to respond to Harlan's arguments and evidence.

A few months later, Reynolds v. Sims ${ }^{46}$ used the Equal Protection Clause to impose the one person, one vote rule on apportionment in state legislatures. Chief Justice Warren's lengthy majority opinion reasoned that any restrictions on the right to vote "strike at the heart of representative government" and that dilution or debasement of the weight of a citizen's vote is tantamount to a denial of the right. ${ }^{47}$ The Court rejected the analogies in the federal Constitution on the ground that they were concessions to political realities in bringing separate

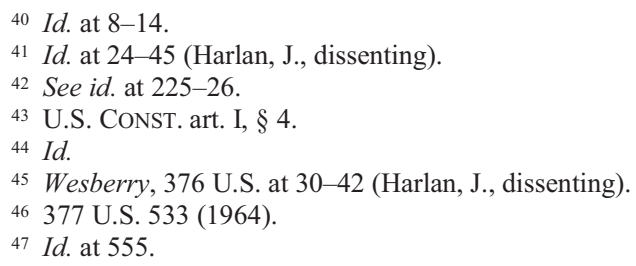


sovereignties into one government. ${ }^{48}$ Recognizing, however, that there may be a variety of reasons that states might legitimately deviate from mathematical equality, the Court suggested that "substantial" equality is good enough, and that "[s]omewhat more flexibility may therefore be constitutionally permissible with respect to state legislative apportionment than in congressional districting." 49

Harlan's dissent boiled the majority's argument down to the "constitutionally frail tautology that "equal' means 'equal."" 50 Even that may be too generous because the majority left open some illdefined space for deviations from equality, and Harlan was confident that the majority's "general considerations" were "not amenable to the development of judicial standards." 51

The bulk of Harlan's opinion is devoted to amassing evidence that the Equal Protection Clause cannot mean "one person, one vote":

First, the text of section 2 of the Fourteenth Amendment provides a very specific and limited remedy for denials or abridgments of the franchise by the state governments: it gives the states a choice between allowing all adult men the right to vote or suffering a proportionate reduction of the state's representation in the House of Representatives (and thus also in the Electoral College). ${ }^{52}$ To conclude that section 1 forbids what section 2 assumes is permissible would approach absurdity. ${ }^{53}$

Second, Harlan collected a great many statements in the ThirtyNinth Congress - including statements from leading proponents of the Fourteenth Amendment - uniformly indicating that it would have no effect on the preexisting right of the states to regulate the franchise. ${ }^{54}$

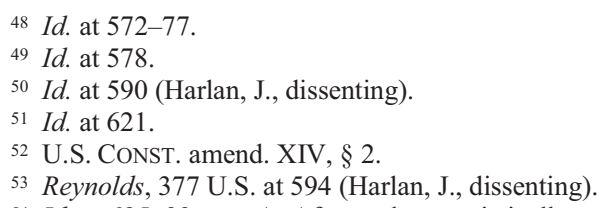

${ }_{54} \mathrm{Id}$. at 625-32 app. A. After a characteristically scrupulous and intelligent review of the proceedings in the Thirty-Ninth Congress, William W. Van Alstyne concludes that Harlan overstated the evidence for an unequivocal consensus that section 2 of the Fourteenth Amendment was meant to provide the exclusive constitutional remedy for restrictions on the suffrage by state governments. William W. Van Alstyne, The Fourteenth Amendment, The "Right" to Vote, and the Understanding of the Thirty-Ninth Congress, 1965 SuP. CT. REV. 33 (1965). On his reading of the evidence, some members of Congress believed that section 2 should be read to leave the powers of the federal government under other provisions unaffected and were concerned in section 2 mainly with assuring that the Republican Party would be able to maintain control of the House of Representatives and the Electoral College. Id. at 65. Van Alstyne concedes that there was an original understanding that section 1 "would not itself immediately invalidate state suffrage laws severely restricting the right to vote." Id. at 72 . Some legislators may have hoped that Congress (not the courts) would eventually use section 5 to grant the vote to the freedmen, but they recognized that if the Amendment were understood to do even that, it would not have been ratified. Id. at 72-73. This impressive scholarly supplement 
Third, he noted that almost two-thirds of the loyal states that ratified the Amendment before 1870 had constitutions providing for unequal apportionment, and in some of them the apportionment was in fact extremely unequal. ${ }^{55}$

Fourth, more than half of the reconstructed states that were readmitted to the union after they ratified the Fourteenth Amendment had new constitutions, approved by Congress, that deviated substantially from the one person, one vote principle. ${ }^{56}$

Fifth, Harlan showed that after ratification, states continued to deliberately exercise the right to apportion their legislatures unequally, and Congress continued to admit new states with unequal apportionment provisions in their constitutions. ${ }^{57}$

Sixth, the majority's holding means that the Fifteenth and Nineteenth Amendments were superfluous anachronisms, unless one supposes that the Fourteenth Amendment dictates certain methods of apportionment without protecting the right to vote itself. ${ }^{58}$

Confident of its prerogative to create new law reflecting a new vision of democratic governance, the majority treated Harlan's legal arguments in these cases with disdainful silence. When one reads the opinions, it is easy to understand why. In each of these cases, Harlan so thoroughly demolished the majority opinion that it is difficult even to imagine what response could have been offered. ${ }^{59}$

to Harlan's legislative history demonstrates at most that the legislative history is not perfectly univocal as to the exact inferences to be drawn from section 2, and that some legislators hoped that Congress would someday seize the power to draw inferences contrary to the meaning of the Constitution as originally understood by its ratifiers. Van Alstyne does not purport to provide any evidence that the ratifiers of the Fourteenth Amendment could have had the slightest inkling that a court might read this constitutional provision to confer the suffrage on black citizens, let alone to require equipopulous districts in state legislatures. Harlan's conclusion about the original meaning of the Fourteenth Amendment thus emerges completely unscathed from Van Alstyne's reinvestigation of the legislative history.

${ }_{55}$ Reynolds, 377 U.S. at 602-04 (Harlan, J., dissenting).

${ }_{56} \mathrm{Id}$. at 604-07.

${ }^{57}$ Id. at $608-11$.

58 Id. at 612.

${ }^{59}$ In the equal protection cases, I suppose one can at least imagine a response along the lines of Justice Stewart's famous definition of hard-core pornography: "I shall not today attempt further to define the kinds of material I understand to be embraced within that shorthand description [of constitutionally unprotected pornography]; and perhaps I could never succeed in intelligibly doing so. But I know it when I see it, and the motion picture involved in this case is not that." Jacobellis v. Ohio, 378 U.S. 184, 197 (1964) (Stewart, J., concurring).

This would have been a manifestly pathetic response to Harlan's detailed and compelling analysis of the Fourteenth Amendment's text and legislative history in Reynolds v. Sims. But even this sort of response could not account for Wesberry v. Sanders. In that case, Justice Black's majority opinion made an extended effort to show that the original meaning of Article I, section 2 entailed the Court's one person, one vote rule. 376 U.S. 1, 17-18 (1964). Harlan demolished every one of Black's arguments and exposed every piece of Black's textual and historical evidence as fraudulent. See id. at 20-49 (Harlan, J., dissenting). Justice Stewart rather 


\section{BUSH V. GORE CORRECTLY APPLIED THE DOCTRINE GENERATED BY BAKER V. CARR}

Whatever one thinks of the Warren Court's democratic theory, or of its cavalier attitude toward the law, one would think that the doctrine it established would be regarded as settled after nearly four decades of acquiescence by the Court and the public. That is certainly what the majority in Bush v. Gore believed. ${ }^{60}$ They saw the case, quite correctly, as a straightforward application of the principle that emerged from Baker v. Carr. That principle, as the Court was soon to formulate it in Reynolds v. Sims, is clear and rhetorically appealing, which no doubt helps to explain its durability:

Weighting the votes of citizens differently, by any method or means, merely because of where they happen to reside, hardly seems justifiable. One must be ever aware that the Constitution forbids sophisticated as well as simpleminded modes of discrimination.... To the extent that a citizen's right to vote is debased, he is that much less a citizen. The fact that an individual lives here or there is not a legitimate reason for overweighting or diluting the efficacy of his vote... This is the clear and strong command of our Constitution's Equal Protection Clause. This is an essential part of the concept of a government of laws and not men. This is at the heart of Lincoln's vision of "government of the people, by the people, [and] for the people."

The Florida Supreme Court order that was vacated by Bush v. Gore was shot through with vote debasement that affected citizens because of where they lived. The order was also very "sophisticated" in the sense that it was complex enough to be somewhat obscure. The Florida court's violation of the Reynolds principle may have been unintentional in the sense that it was not motivated by a desire to discriminate against certain classes of voters or to favor one of the presidential candidates. But it certainly did violate what Reynolds

tactfully said that Harlan had "unanswerably demonstrated" that the Court's decision was wrong. Id. at 51 (Stewart, J., dissenting).

60 Some originalists might think that the Court should have used Bush v. Gore as an occasion to overrule Baker v. Carr and all of its progeny. No one on the Supreme Court made any such suggestion, and I am not aware that any commentator has done so either.

61377 U.S. 533, 563, 567-68 (1964) (alteration in original) (emphasis added) (citations and internal quotation marks omitted). Not content with improving the Constitution, Chief Justice Warren (or a pedantic law clerk) went so far as to "correct" Lincoln's diction. Amazing. 
called "the clear and strong command of our Constitution's Equal Protection Clause." 62

Elsewhere, I have explained in detail why the Supreme Court's decision was correct under its precedents, and defended that conclusion against a variety of objections. ${ }^{63}$ As far as I am aware, my arguments stand unrefuted. ${ }^{64}$ The key point is that the Florida court effected a paradigmatic form of vote debasement.

In Baker v. Carr itself, Justice Brennan cited several precedents for the proposition that the Constitution is violated by state actions that dilute votes by false tallies, by refusals to count votes from arbitrarily selected precincts, or by stuffing the ballot box. ${ }^{65}$ What the Florida Supreme Court ordered was analytically indistinguishable from these forms of manipulative vote counting.

In Bush v. Gore, one candidate had narrowly lost the election as determined both in an initial count of the ballots and in a recount, both of which were tabulated primarily by ballot-counting machines. ${ }^{66}$ The Florida court ordered a revision of vote totals based on hand recounts in a few counties strategically selected by one of the candidates because of his party's dominance in those jurisdictions, and conducted by local officials who had been chosen in partisan elections. ${ }^{67}$ The court even ordered that votes be definitively added to this candidate's total from an uncompleted recount in one county that had begun with precincts that historically favored his party. The recounts, moreover, had used different counting standards, and at least one county had repeatedly changed its counting rules in the

$62 \mathrm{Id}$. at 568 . No finding of intentional discrimination is required in the fundamental rights branch of equal protection law under which Bush v. Gore was decided. Not only has the Court never articulated such a requirement, but there is at least one case in which there was manifestly no discriminatory purpose at work. See O’Brien v. Skinner, 414 U.S. 524, 530 (1974) (invalidating state law that permitted absentee voting only by voters who were not in their county of residence on election day, thus producing unforeseen disparate effects on prisoners depending on whether they were jailed inside or outside their home county). $C f$. Laurence $\mathrm{H}$. Tribe, eroG v. hsuB and its Disguises: Freeing Bush v. Gore from its Hall of Mirrors, 115 HARV. L. REV. 170, 225 (2001) [hereinafter Tribe, eroG v. hsuB] (mistakenly supposing that the absence of a finding of purposeful discrimination by the Florida Supreme Court was relevant in Bush v. Gore).

63 See supra note 5 and infra note 64 (listing articles defending Bush v. Gore).

64 I know of only one effort to challenge my arguments, and I believe I have already shown that this challenge failed. Interested readers can make up their own minds by reviewing the following colloquy. See Nelson Lund, "EQUAL PROTECTION, MY ASS!'?: Bush v. Gore and Laurence Tribe's Hall of Mirrors, 19 CONST. COMM. 543 (2002); Laurence H. Tribe, The Unbearable Wrongness of Bush v. Gore, 19 CONST. COMM. 571 (2002) [hereinafter Tribe, Unbearable Wrongness]; Nelson Lund, Carnival of Mirrors: Laurence Tribe's "Unbearable Wrongness," 19 Const. Comm. 609 (2002); Laurence H. Tribe, Lost at the Equal Protection Carnival: Nelson Lund's Carnival of Mirrors, 19 Const. CoMM. 619 (2002).

65369 U.S. 1, 208 (1962).

66531 U.S. 98,100 (2000).

67 Id. at $101-02$. 
course of the recount. ${ }^{68}$ The Florida court also ordered a selective recount in Miami-Dade County that would include only the ballots selected by the losing candidate, and a selective statewide recount of the same kind of ballots this candidate had selected in Miami-Dade. ${ }^{69}$ The selective statewide recount was to be performed without any uniform standard for distinguishing valid from invalid ballots, and contemporaneous objections by the candidates' representatives were disallowed. $^{70}$

Even assuming that every vote added to the totals during the recount correctly adjusted a mistake by the ballot-counting machines, voters in different places were being treated very differently. There is no meaningful difference between stuffing the ballot box with invalid votes and selectively adding valid votes to the final total. The courtordered recount was at best a somewhat less egregious version of a recount in which mistakes favoring one candidate are corrected and mistakes favoring the other candidate are ignored. Three of the seven judges on the Florida Supreme Court (all of whom were Democratic appointees) protested that this utterly bizarre recount order violated both Florida law and the federal Constitution, ${ }^{71}$ and a majority of the U.S. Supreme Court agreed that it violated the Equal Protection Clause. The most troubling feature of Bush v. Gore is that it was not unanimous.

Two Justices, however, could find no violation of the Equal Protection Clause. Justice Stevens refused even to look for a violation. Why? Because finding one might call into question other election practices that were not before the Court, and because " $[\mathrm{t}] \mathrm{he}$ interpretation of constitutional principles must not be too literal. We must remember that the machinery of government would not work if it were not allowed a little play in its joints." ${ }^{, 72}$ Whatever merit this point may have in other contexts, it is a remarkable response both to the facts of this case and to the legal analysis set forth in the majority opinion. And it is one that could be used to reject the holding in every single one of the Court's seminal one person, one vote decisions.

For her part, Justice Ginsburg claimed that there was no substantial equal protection claim in the case because the Florida hand recount might be no worse than the previous machine counts. ${ }^{73}$ Why she

68 See id. at 107.

69 Id. at $107-08$.

70 Id. at 109.

71 Gore v. Harris, 772 So. 2d. 1243, 1265 (Fla. 2000) (Wells, J., dissenting), rev'd sub nom. Bush v. Gore, 531 U.S. 98 (2000); id. at 1270 (Harding, J., dissenting)

72 Id. at 126 (Stevens, J., dissenting) (quoting Bain Peanut Co. of Tex. v. Pinson, 282 U.S. 499, 501 (1931)) (internal quotation marks omitted).

73 Id. at 143 (Ginsburg, J., dissenting). 
would think so is anyone's guess, for no constitutional challenge to the machine counts had been raised in the litigation, and no evidence of equal protection violations in those tabulations had been presented. If there were any legal basis for Ginsburg's unsupported speculation, it would apparently have to rest on her invocation of the Williamson v. Lee Optical principle. ${ }^{74}$ That, of course, is the very case that Justice Harlan cited for his unimpeachable claim that Baker v. Carr marked a dramatic departure from prior law. ${ }^{75}$ It is impossible to believe that Ginsburg would actually revive Lee Optical as the controlling precedent in Fourteenth Amendment voting cases. We are therefore left to wonder whether the Florida court's recount order looked perfectly constitutional to her because that order rather resembled her own application of equal protection principles. In any event, it turns out that even Lee Optical does not support Ginsburg's position, as I will argue in Part III below.

Justices Souter and Breyer at least did not deny that the Florida court's recount order was unconstitutional. Both of them focused on the varying treatment that similar ballots received in different counties or at different times during the recount. Souter found several features of the recount "wholly arbitrary." "76 Breyer's more convoluted comments concluded that at least one aspect of the recount appeared to violate "basic principles of fairness."

Why then did they dissent? ${ }^{78}$ Both of them would have sent the case back to the Florida courts "with instructions to establish uniform standards for evaluating the several types of ballots that have prompted differing treatments, to be applied within and among counties when passing on such identical ballots in any further

74 Id.

75 See Baker v. Carr, 369 U.S. 186, 333-34 (1962) (Harlan J., dissenting) (citing Lee Optical for the governing rational basis test in equal protection cases).

76 Bush, 531 U.S. at 134 (Souter, J., dissenting).

${ }^{77}$ Id. at 146 (Breyer, J., dissenting). As far as I can tell, Breyer used "basic principles of fairness" as a kind of shorthand for the requirements of the Fourteenth Amendment. That is apparently how Justice Stevens understood him, for Stevens declined to join those portions of Breyer's opinion that seemed inconsistent with his own view that "[t]he federal questions that ultimately emerged in this case are not substantial." Id. at 123 (Stevens, J., dissenting). But because Breyer joined Stevens' opinion in full, and Souter's as well, some mystery remains about Breyer's precise position, assuming he had one. Cf. Akhil Reed Amar, Bush, Gore, Florida, and the Constitution, 61 FLA. L. REV. 945, 966-67 (2009) (concluding that Breyer's position is incoherent).

78 Their opinions should have been labeled concurring in part and dissenting in part. See Arthur J. Jacobson, The Ghostwriters, in The Longest Night: Polemics AND PersPeCtives ON ELECTION 2000, 189, 206 (Arthur J. Jacobson \& Michel Rosenfeld eds., 2002). Such a label, however, would have made it harder for the media to call this a 5-4 decision. It is more than odd that Justices who professed to be so worried about the effects of a narrowly divided decision on the public's perceptions of the Court's legitimacy would misleadingly characterize their own opinions in a way that could only exacerbate such perceptions. 
recounting (or successive recounting) that the courts might order."79 As the Bush v. Gore majority correctly pointed out, instructing the Florida courts to establish new standards for a new recount would have been illegal. ${ }^{80}$

Souter and Breyer had nothing to say about the majority's reason for rejecting their proposed remedy. Perhaps that is because the majority offered only a legal reason for its decision. Souter and Breyer had what they apparently regarded as a much more fundamental objection to everything the majority had done. They maintained that the Court was wrong to review any of the Florida Supreme Court's decisions, including a decision that the U.S. Supreme Court had unanimously vacated, and they obviously would have opposed reviewing almost any future decision of the Florida court in this matter.

Because the Court was exercising a discretionary jurisdiction, such judicial passivity would at least have had the merit of not being illegal. But neither did it have any basis in the law. Under Baker v. Carr, no one could seriously maintain that Bush v. Gore presented a nonjusticiable political question. Accordingly, none of the parties even mentioned the political question doctrine, and none of the dissenters claimed that the case was nonjusticiable ${ }^{81}$ Nor is there any

79 Bush, 531 U.S. at 134-35 (Souter, J., dissenting).

80 The Florida Supreme Court had already ruled that the time for recounts had expired under state law on the same day that Bush v. Gore was decided. See id. at 110 (majority opinion). The U.S. Supreme Court had no authority to revise that state-law determination. Breyer, who joined Souter's opinion, wrote in his own dissent:

An appropriate remedy would be, instead, to remand this case with instructions that, even at this late date, would permit the Florida Supreme Court to require recounting all undercounted votes in Florida, including those from Broward, Volusia, Palm Beach, and Miami-Dade Counties, whether or not previously recounted prior to the end of the protest period, and to do so in accordance with a single uniform standard.

Id. at 146 (Breyer, J., dissenting). Except for his use of the word "undercounted," Breyer's proposed instructions appear to be indistinguishable from the instructions that the majority gave, for the majority's instructions permitted the Florida court to reinterpret state law to provide additional time to attempt a new recount. See $i d$. at 111 (majority opinion) (refusing to order a remedy that would violate Florida law as interpreted by the Florida Supreme Court, while leaving the Florida court free to revise its interpretation of state law on remand). The fact that Breyer and Souter joined each other's opinions seems to imply that they either were advocating an illegal act or had no grounds on which to dissent. For a more detailed analysis of the majority's instructions on remand, see Lund, Unbearable Rightness, supra note 5, at 1274-78.

81 Although he never mentioned this doctrine in the briefs he filed in the case, Professor Tribe later mocked the Court for not addressing it and claimed that the Constitution "commanded the Court ... not to inject itself into the dispute." Tribe, eroG.v hsuB, supra note 62, at 279-80 (2001). Under pressure, Professor Tribe eventually backed away from this claim. See Tribe, Unbearable Wrongness supra note 64, at 593, 606-07 (2002) ("I approached this question too mechanically the first time around. ... [Later] I leaned too far in the direction of nonjusticiability, in essence overcompensating for my earlier assumption of justiciability."). He then went on to formulate yet a third version of the political question doctrine, which he 
legal principle that requires (or even invites) the Court to decline jurisdiction over controversial cases whose resolution might expose the Court to politically motivated attacks. Even assuming for the sake of argument that Souter and Breyer were right to think that the Court imprudently granted the petition for certiorari, that could not possibly justify dissenting from the decision on the merits. Hence their undefended - and I believe indefensible — objection to the Court's remedial order.

\section{BUSh V. Gore WAS Legally CORReCt Under PRE-BAKER DOCTRINE}

Part of what makes Bush v. Gore so easy to justify under the precedents is this statement in Baker v. Carr:

A citizen's right to a vote free of arbitrary impairment by state action has been judicially recognized as a right secured by the Constitution, when such impairment resulted from dilution by a false tally, ... or by a refusal to count votes from arbitrarily selected precincts, ... or by a stuffing of the ballot box. $^{82}$

This was not a throwaway line. The Court repeated the point, citing the same precedents, in each of its next three vote-dilution cases. ${ }^{83}$ Because the Florida Supreme Court's recount order had effects analytically indistinguishable from these forms of vote dilution, and because the Baker v. Carr line of voting rights cases has never required a showing of discriminatory intent, that recount order fell squarely within Reynolds' prohibition against "[w]eighting the votes of citizens differently, by any method or means, merely because of where they happen to reside. . .." 84

As it happens, however, none of the four cases cited in Baker $v$. Carr was an equal protection decision. All of them involved the application of a federal statute enacted under Congress's authority to regulate the "Times, Places, and Manner of holding Elections for Senators and Representatives." ${ }^{\prime 25}$ There can be no doubt that Congress

apparently believes that someone on the Supreme Court should have discovered (or invented) without his assistance during the litigation in which he played a leading role. See id. at 593-603.

82369 U.S. 186, 208 (1962) (citing United States v. Saylor, 322 U. S. 385 (1944), United States v. Classic, 313 U. S. 299 (1941), United States v. Mosley, 238 U. S. 383 (1915), and Ex parte Siebold, 100 U. S. 371 (1879)).

83 Wesberry v. Sanders, 376 U.S. 1, 17 (1964); Reynolds v. Sims, 377 U.S. 533, 554-55 (1964); Gray v. Sanders, 372 U.S. 368, 380 (1963).

${ }^{84}$ Reynolds, 377 U.S. at 563 (emphasis added).

85 U.S. CONST. art. I, $\S 4$, cl. 1. In United States v. Classic, the Court expressly declined to 
has the authority to ban vote dilution through mechanisms like stuffing the ballot box in elections for federal offices. But that in no way implies that the Constitution contains a more general requirement of equipopulous districts in federal elections, let alone in state elections. This was one of Justice Harlan's central points in Wesberry v. Sanders. ${ }^{86}$

The misleading manner in which the Baker v. Carr majority used these precedents is another example of that Court's cavalier attitude toward the law. As we have seen, Justice Brennan distinguished away numerous decisions upholding unequal apportionment on the ground that they were Guarantee Clause cases rather than Equal Protection Clause cases. Here, on the other hand, he deceptively invoked irrelevant statutory decisions rooted in Article I in support of a constitutional decision under the Equal Protection Clause.

The pervasive lawlessness in Baker v. Carr and its early progeny might suggest that the Court should have been reluctant to extend the reach of this line of doctrine to presidential elections in Bush v. Gore. This conclusion might seem especially attractive because Bush v. Gore could have been decided under Article II, as Chief Justice Rehnquist's concurrence proposed. ${ }^{87}$ Such a decision would have had the advantage of relying on an analysis of the Constitution, rather than on a line of cases whose basis in the Constitution has never been identified by the Court and is apparently nonexistent. Perhaps that is what the Court should have done in Bush v. Gore, although the Article II argument is not free of its own difficulties. ${ }^{88}$

Whatever one thinks of Rehnquist's Article II argument, the equal protection holding in Bush v. Gore would have been correct even without any reliance on Baker v. Carr and its progeny. To see why, it is helpful to focus on a neglected distinction between Bush v. Gore and other vote-dilution decisions. Previous cases involved legislative actions that had a plausible rationale or executive actions that violated statutes enacted by legislatures. Bush v. Gore was extraordinary because it involved an election practice so bizarre that no legislature would ever adopt it, and it is no accident that the closest analogues in the case law involved criminal behavior by executive officials. The

decide whether the state action at issue in the case violated the Equal Protection Clause. 313 U.S. 299, 329 (1941).

86 See 376 U.S. 1, 29-42 (Harlan, J., dissenting).

87 Bush v. Gore, 531 U.S. 98, 111-22 (Rehnquist, C.J., concurring). All three Justices who joined Rehnquist's concurrence also joined the majority opinion.

88 For a brief discussion of the difficulties, see Lund, Unbearable Rightness, supra note 5, at $1265-67$. 
recount challenged in Bush v. Gore, by way of contrast, was designed by a court, an institution with special obligations to refrain from arbitrary actions and to explain the actions it takes.

The Florida recount order failed even the extremely forgiving rational basis standard that Justice Harlan rightly thought was applicable in Baker v. Carr. Under that standard, the Equal Protection Clause prohibits invidious discrimination bearing no rational relation to any permissible policy of the State, while permitting discrimination if any state of facts reasonably may be conceived to justify it. ${ }^{89}$ The Florida Supreme Court majority purported to identify rational relations between the various elements of the recount order and the permissible state policy that elections should be determined by "the will of the voters" rather than by "strategies extraneous to the voting process." $" 90$ This policy, however, cannot possibly explain the Florida court's actual ruling. That ruling was based on a very different policy, one never stated in the opinion, which was pretty much the opposite of the stated policy.

The real policy went something like this. Once a machine counts the ballots, we will allow the loser to choose which ballots to reexamine by hand. Any changes in the vote totals resulting from this selective, partial, and biased recount will be adopted. But because this would so manifestly allow the outcome to turn on "strategies extraneous to the voting process," we will try to create what we regard as a tolerable approximation of evenhandedness by directing the trial court to make an effort to perform a somewhat less selective, somewhat less partial, and somewhat less biased recount than the losing candidate had demanded.

If the Florida Supreme Court had actually been seeking to ascertain the "will of the voters" of Florida, it would have designed a statewide recount that could believably be called more accurate or

89 Baker v. Carr, 369 U.S. 186, at 334-35 (Harlan, J., dissenting) (citing Lee Optical and McGowan v. Maryland). Lee Optical's use of the word "invidious" obviously does not imply that a violation of equal protection can only be found when there is a showing of intentional discrimination against an identifiable individual or group. Such a showing is now required under the so-called suspect classifications branch of equal protection doctrine, which governs claims of discrimination based on personal characteristics like race. See, e.g., Miller v. Johnson, 515 U.S. 900 (1995). The requirement of intentional discrimination, however, is not a general rule of equal protection law, which is why it has never been applied in voting rights cases that do not involve claims of racial discrimination, or in cases involving economic regulations like Lee Optical. State action that fails the minimum rationality test is unconstitutional whether or not it is motivated by an intent to discriminate against a disfavored class of individuals. In the context of Bush v. Gore, it is therefore irrelevant whether the Florida court intended to discriminate against George Bush or those who voted for him.

90 Gore v. Harris, 772 So.2d 1243, 1253 (Fla. 2000), rev'd sub nom. Bush v. Gore, 531 U.S. $98(2000)$. 
more reliable than the initial machine counts. ${ }^{91}$ At an absolute minimum, that would have required reexamining all the "overvotes" (ballots on which the machines detected a vote for more than one candidate, and therefore recorded no vote) as well as the "undervotes" (ballots on which the machines detected no vote for any candidate). Once one assumes that the "intent of the voter" should be honored even when the voter failed to comply with the instructions on how to vote, these two categories of ballots become logically indistinguishable. ${ }^{92}$ The statewide recount, however, applied only to "undervote" ballots. ${ }^{93}$

Furthermore, the need to treat "undervotes" and "overvotes" the same way is only the most obvious requirement of a recount aimed at determining the will of the voters. If one were actually serious about designing a recount that was more accurate than the machine counts, one would also have to recount all of the ballots identified by the machines as "legal votes." Whatever criterion is adopted for changing "undervotes" to "legal votes" (for example, the presence of hanging chad, or the presence of dimpled chad), that same criterion would have to be applied to ballots containing both a machine-readable hole and a hanging or dimpled chad. That means that some "legal votes" would have to be changed to "overvotes," and thus deducted from the vote totals. This could have been quite significant because ballots containing both a clean hole for one candidate and a dimpled or indented chad for another candidate were quite common in the Florida election. ${ }^{94}$ Alternatively, the court might have been justified in restricting a recount to "undervote" ballots if it had employed a standard designed to count the ballots of those voters whose efforts

91 This is exactly the point that Judge Sauls (whom the Florida Supreme Court was reversing) made when he said:

[U]nder Section 102.168 of the Florida Statutes to contest a statewide federal election, the Plaintiff would necessarily have to place at issue and seek as a remedy with the attendant burden of proof, a review and recount [of] all ballots, and all of the counties in this state with respect to the particular alleged irregularities in the balloting or counting processes alleged to have occurred.

Transcript of Oral Ruling at 12-13, Gore v. Harris, 772 So.2d 1243 (2000) (No. 00-2808), available at http://election2000.stanford.edu/00-2431_transcript.pdf.

92 The Florida majority was certainly aware of this completely obvious point because Chief Justice Wells insisted on it in his dissent. See Gore, 772 So.2d at 1264-65 n.26 (Wells, C.J., dissenting) ("The underlying premise of the majority's rationale is that in such a close race a manual review of ballots rejected by the machines is necessary to ensure that all legal votes cast are counted. The majority, however, ignores the over-votes.").

93 See id. at 1262 (majority opinion).

94 See, e.g., Contest Trial Transcript at 262-64, Gore v. Harris, 772 So.2d 1243 (2000) (No. 00-2808), available at http://election2000.stanford.edu (testimony of Judge Charles Burton about ballots with these characteristics). 
were frustrated by faulty machines, without counting the ballots of voters who failed to follow the instructions. But the Florida court insisted upon the proposition that "a legal vote is one in which there is a "clear indication of the intent of the voter," with or without evidence of a faulty machine. ${ }^{95}$

Thus, the Florida Supreme Court could not have been seeking to ascertain the will of the voters of Florida. Instead, it was seeking to ascertain the will of a peculiar subset of Florida voters, namely those who had cast "undervote" ballots and those other voters who both happened to reside in the heavily Democratic counties Gore had strategically selected for full recounts and who happened to reside in the even more heavily Democratic precincts in which such recounts had actually been conducted. This choice, for which the court gave no explanation, might charitably be described as extraordinarily capricious. ${ }^{96}$

When reviewing legislation under the rational basis test, courts often imagine or hypothesize legitimate reasons for the law. This makes considerable sense because legislatures need not, and frequently do not, explain why they chose to act as they did. But courts are different, and the Florida court in particular did give reasons for its decision. The complete disconnect between the actual decision and the "permissible state policy" it supposedly advanced exposes the decision of the Florida majority as itself irrational. There is no need to make an effort to imagine a rational basis for the recount order because the Florida court's judicial opinion shows that none existed.

95 Gore, 772 So.2d at 1257 (apparently quoting Fla. Stat. § 101.5614(5) (2000)—which applies only to damaged or defective ballots - but clearly adopting the quoted standard as a general principle applicable to all ballots subject to manual recounts).

96 Justice Breyer later tried to supply an explanation by pointing out that Bush and the other defendants in the case "presented no evidence, to this Court or to any Florida court, that a manual recount of overvotes would identify additional legal votes." Bush v. Gore, 531 U.S. 98, 145 (Breyer, J., dissenting). This argument is patently untenable, and even fantastic. First, the only "evidence" cited by the Florida Supreme Court for the proposition that the undervote ballots included some additional "legal votes" was the mere existence of 9,000 undervote ballots from Miami-Dade. Gore, 772 So. 2 d at 1256. Second, there was not even that much "evidence" of undervotes in counties other than those selected by Gore for recounts, yet the Florida courts were conducting a manual recount of undervotes in all Florida counties. Third, the defendants in the lawsuit had no occasion to present "evidence" to support a legal theory that they were not advancing. In fact, they had no reason even to think of such a theory until after the Florida Supreme Court ordered, sua sponte and quite unexpectedly, a statewide recount of "undervote" ballots. Fourth, Gore's own lawyer acknowledged to the U.S. Supreme Court that there were approximately 110,000 "overvote" ballots in Florida, a rather significant number in an election that was decided by a margin of 537 votes. Transcript of Oral Argument at 62, Bush v. Gore, 531 U.S. 98 (2000) (No. 00-949), available at http://www.supremecourt.gov/oral_arguments/argument_transcripts/00-949.pdf. 
Courts applying similar standards of review to jury verdicts and to administrative adjudications may find it easier to conclude that administrative actions lack adequate support. ${ }^{97}$ Similarly, it is even easier to see that the Florida recount had no rational basis than it would be if a statute had compelled a similarly bizarre way of resolving a disputed election. That no statute ever has (or would) dictate such a biased recount reinforces the manifest irrationality of the Florida Supreme Court's order. Thus, even if Baker v. Carr had never given birth to the precedents that made Bush v. Gore an exceedingly easy case, the Supreme Court's decision in the Florida election case would still have been correct under well-established equal protection law.

\section{CONCLUSION}

Baker v. Carr is widely revered, often by the same people who see Bush v. Gore as something like the crime of the century. Both views are wrong, but the second is doubly wrong. Baker v. Carr and its progeny compelled the Supreme Court's decision in the Florida election case, but it would have been legally correct even if those precedents had not existed.

In one sense, however, the outrage against Bush v. Gore does have deep roots in the Court's early one person, one vote jurisprudence: both are rooted in an implacable urge to conflate the rule of law with what Justice Harlan called a "political ideology." 98 The Baker v. Carr dissenters may have underestimated the Court's ability to pull off its ideological program of political reform, but they did not misunderstand its fundamental betrayal of the law. The Bush v. Gore majority refused to repeat that betrayal, which has triggered denunciations of the Court that reflect one of Baker v. Carr's most poisonous legacies.

\footnotetext{
97 See, e.g., GARY LAWSON, FedERAL Administration LAw 377, 384 (4th ed. 2007)

98 Reynolds v. Sims, 377 U.S. 533, 590 (1964) (Harlan, J., dissenting).
} 